\title{
Isolation and characterization of microsatellite markers from the olive fly, Bactrocera oleae, and their cross-species amplification in the Tephritidae family
}

\author{
Antonios A Augustinos ${ }^{1,2}$, Elias E Stratikopoulos ${ }^{1,4}$, Eleni Drosopoulou ${ }^{3}$, \\ Evdoxia G Kakani², Penelope Mavragani-Tsipidou ${ }^{3}$, \\ Antigone Zacharopoulou ${ }^{1}$ and Kostas D Mathiopoulos*2
}

Address: ${ }^{1}$ Department of Biology, University of Patras, Patras, Greece, ${ }^{2}$ Department of Biochemistry and Biotechnology, University of Thessaly, Thessaly, Greece, ${ }^{3}$ Department of Biology, Aristotle University of Thessaloniki, Thessaloniki, Greece and ${ }^{4}$ Department of Genetics and Development, Columbia University, New York, NY 10032, USA

Email: Antonios A Augustinos - augustin@upatras.gr; Elias E Stratikopoulos - is2193@columbia.edu;

Eleni Drosopoulou - edrosopo@bio.auth.gr; Evdoxia G Kakani - evkakani@bio.uth.gr; Penelope Mavragani-Tsipidou - mavragan@bio.auth.gr; Antigone Zacharopoulou - zacharop@upatras.gr; Kostas D Mathiopoulos* - kmathiop@bio.uth.gr

* Corresponding author

Published: 19 December 2008

BMC Genomics 2008, 9:618 doi:I0.1 I86/I47I-2164-9-618

This article is available from: http://www.biomedcentral.com/I47|-2/64/9/6/8

(c) 2008 Augustinos et al; licensee BioMed Central Ltd.

This is an Open Access article distributed under the terms of the Creative Commons Attribution License (http://creativecommons.org/licenses/by/2.0), which permits unrestricted use, distribution, and reproduction in any medium, provided the original work is properly cited.
Received: II October 2008

Accepted: 19 December 2008

\begin{abstract}
Background: The Tephritidae family of insects includes the most important agricultural pests of fruits and vegetables, belonging mainly to four genera (Bactrocera, Ceratitis, Anastrepha and Rhagoletis). The olive fruit fly, Bactrocera oleae, is the major pest of the olive fruit. Currently, its control is based on chemical insecticides. Environmentally friendlier methods have been attempted in the past (Sterile Insect Technique), albeit with limited success. This was mainly attributed to the lack of knowledge on the insect's behaviour, ecology and genetic structure of natural populations. The development of molecular markers could facilitate the access in the genome and contribute to the solution of the aforementioned problems. We chose to focus on microsatellite markers due to their abundance in the genome, high degree of polymorphism and easiness of isolation.
\end{abstract}

Results: Fifty-eight microsatellite-containing clones were isolated from the olive fly, Bactrocera oleae, bearing a total of sixty-two discrete microsatellite motifs. Forty-two primer pairs were designed on the unique sequences flanking the microsatellite motif and thirty-one of them amplified a PCR product of the expected size. The level of polymorphism was evaluated against wild and laboratory flies and the majority of the markers (93.5\%) proved highly polymorphic. Thirteen of them presented a unique position on the olive fly polytene chromosomes by in situ hybridization, which can serve as anchors to correlate future genetic and cytological maps of the species, as well as entry points to the genome. Crossspecies amplification of these markers to eleven Tephritidae species and sequencing of thirty-one of the amplified products revealed a varying degree of conservation that declines outside the Bactrocera genus.

Conclusion: Microsatellite markers are very powerful tools for genetic and population analyses, particularly in species deprived of any other means of genetic analysis. The presented set of microsatellite markers possesses all features that would render them useful in such analyses. This could also prove helpful for species where SIT is a desired outcome, since the development of effective SIT can be aided by detailed knowledge at the genetic and molecular level. Furthermore, their presented efficacy in several other species of the Tephritidae family not only makes them useful for their analysis but also provides tools for phylogenetic comparisons among them. 


\section{Background}

The Tephritidae family of insects includes the most important agricultural pests of fruits and vegetables. Most of them belong to four genera: Bactrocera, Ceratitis, Anastrepha and Rhagoletis. Ceratitis includes 89 different species. Among them, the Medfly, Ceratitis capitata, is the best so far studied member of the family and attacks over 350 different fruits and vegetables in tropical and sub-tropical regions [1], causing damages of hundreds of billions \$ per year. Anastrepha is the most economically important genus of pests in the American tropics and subtropics and includes more than fifteen economically important pests [2]. Rhagoletis includes more than 60 described species distributed in Eurasia and the New World, several of which are important pests [3]. Bactrocera is among the largest genera in Tephritidae including about 500 species $[4,5]$. Many of them are serious pests of fruits and vegetables in different parts of the world [2]. The only member of this genus present in Europe is the olive fruit fly, Bactrocera oleae, the major pest of the olive fruit, with estimated damages of $5-30 \%$ of the global olive production, resulting in economic losses of about 800 million \$ per year [6,7]. Quarantine orders against non-indigenous Tephritidae exist in all countries, demonstrating the appreciation of these species' destructive abilities and invasiveness success [8-12].

Currently, control of these insects is based on chemical insecticides. The Sterile Insect Technique (SIT) is the most promising, environmentally friendly method, based on the mass production and release of sterile insects into field populations. When the released males mate with the field females no progeny are produced and the field population may finally be suppressed. The appreciation of the negative effect of the released females [13] lead to the development of genetic sexing strains (GSS) [14]. Successful development of such approaches, however, presupposes an understanding of the species at the genetic, molecular and population level. Additionally, new molecular and genetic tools, such as genetic transformation, could prove very helpful since they can improve mass rearing of effective male insects. Such knowledge developed in the Medfly lead to successful SIT protocols (for a review, see [15]), whereas respective lack in the olive fly lead to fruitless attempts. In the early '70s, efforts to employ the SIT against the olive fly were unsuccessful [16], principally due to the low competitiveness of the sterile mass-reared males compared to the wild ones [17]. Several molecular and genetic studies have changed $B$. oleae's research landscape in recent years. Among them we mention studies on population genetics [18-20], cytogenetics (for a review see [21]), sex-determining cascades $[22,23]$ and, most notably, the successful genetic transformation [24], an achievement that gives new perspectives towards the efficient use of the SIT.
Microsatellites constitute very powerful genetic and molecular markers [25-27]. In the Medfly they have been used to identify sources of origin, invasion phenomena, to design control strategies [28-31], as well as in the genetic mapping of the species [32]. This last possibility renders microsatellite markers particularly useful in the olive fly, since several years of efforts have provided no morphological markers and therefore the development of classical genetics has been entirely hindered (Mavragani, unpublished; Zacharopoulou, unpublished). In addition, such markers can also be helpful in SIT development. For example, they have been successfully used in the analysis of mating systems in B. dorsalis [33] and C. capitata $[34,35]$ and they can be used to detect the degree of differentiation between laboratory and wild flies, the main reason of SIT failure in the olive fly.

The present study enriches a previously described set of 15 microsatellite markers $[36,19]$ with 16 new ones. Most of these markers were proven polymorphic, some of them were localized in the polytene chromosomes of the species and many of them were successfully cross-amplified in other Tephritidae species. Their utility in genetic studies and evolutionary comparisons is considered.

\section{Results and discussion Isolation and characterization of microsatellites from small-insert genomic libraries and enriched libraries}

Thirty-four microsatellite containing clones were isolated from small-insert genomic libraries and 24 from enriched libraries, yielding a total of 36 and 26 discrete microsatellite motifs, respectively, since a few of them contained more than one microsatellite motif (Table 1). Despite the use of an equal mix of $(\mathrm{GT})_{15}$ and $(\mathrm{CT})_{15}$ as probes, there was a clear predominance of GT over CT repeats obtained from the small-insert library. This most likely reflects a difference in the abundance of these sequences in the genome, as has been the case in other Diptera, such as $D$. melanogaster [37-39], D. simulans [40], A. gambiae [41] and C. capitata (Stratikopoulos et al., submitted) [28]. In hymenoptera, CT repeats seem to be more abundant than GT repeats, as studies in Apis mellifera and Bombus terrestris reveal [42].

A significant predominance of interrupted (60.5\%) over perfect motifs $(34.2 \%)$ was observed in both isolation approaches, while only a few $(5.2 \%)$ were compound. These percentages are quite similar to those observed in $C$. capitata [28] and B. terrestris [42]. On the other hand, they are not in agreement with results from B. tryoni [43], $B$. morii [44], D. pseudoobscura [45] and a recent study in $C$. capitata (Stratikopoulos et al., submitted). Therefore, it is unclear whether these results represent the actual structure of microsatellites in the olive fly genome, since data from closely related species are conflicting. Possibly these 
Table I: Microsatellite loci motif and in situ localization to polytene chromosomes

\begin{tabular}{|c|c|c|c|c|c|}
\hline & Accession number & Locus name & Motif & Map position & $\mathbf{T}\left({ }^{\circ} \mathrm{C}\right)$ \\
\hline I & EU489746 & Boms I & $(\mathrm{GT})_{13}$ & - & \\
\hline 2 & AF46783I & Boms2 & $(\mathrm{CA})_{8} \mathrm{TA}(\mathrm{CA})_{3}$ & 4 (IL) & 58 \\
\hline 3 & EU489747 & Boms3 & $\begin{array}{c}(\mathrm{GT})_{14} \\
(\mathrm{CAA})_{3} \mathrm{CAG}(\mathrm{CAA})_{3}\end{array}$ & no specific signal & \\
\hline 4 & EU489748 & Boms 4 & $(\mathrm{GT})_{15} \mathrm{GC}(\mathrm{GT})_{3} \mathrm{GC}(\mathrm{GT})_{13} \mathrm{GA}(\mathrm{GT})_{4}$ & - & \\
\hline 5 & EU489749 & Boms5 & $(\mathrm{CA})_{10} \mathrm{TA}(\mathrm{CA})_{2}$ & 95 (VR) & \\
\hline 6 & EU489750 & Boms6 & $\begin{array}{c}(\mathrm{CA})_{9} \\
(\mathrm{GT})_{3} \mathrm{GG}(\mathrm{GT})_{11} \mathrm{TT}(\mathrm{GT})_{2}\end{array}$ & - & \\
\hline 7 & EU48975I & Boms7 & $(\mathrm{CA})_{7} \mathrm{CC}(\mathrm{CA})_{3}$ & - & \\
\hline 8 & EU489752 & Boms8 & $(\mathrm{CA})_{7} \mathrm{CG}(\mathrm{CA})_{5}$ & - & \\
\hline 9 & EU489753 & Boms9 & $(\mathrm{GT})_{10} \mathrm{CTGA}(\mathrm{GT})_{3}$ & - & \\
\hline 10 & AF467830 & Boms 10 & $(\mathrm{CA})_{10} \mathrm{GA}(\mathrm{CA})_{2}$ & no specific signal & $55-62$ \\
\hline 11 & AF467832 & Boms II (Bo-D37) & $(\mathrm{CA})_{7} \mathrm{CG}(\mathrm{CA})_{3}$ & - & \\
\hline 12 & EU489754 & Boms 12 & $(\mathrm{CA})_{10} \mathrm{AACA}$ & 26 (IIL) & 58 \\
\hline 13 & EU489755 & Boms / 3 & GTGA $(G T)_{10}$ & - & \\
\hline 14 & EU489756 & Boms / 4 & $(\mathrm{AT})_{2} \mathrm{GT}(\mathrm{AT})_{\mathrm{II}}$ & - & \\
\hline 15 & EU489757 & Boms / 5 & $(\mathrm{GT})_{1,} \mathrm{GA}(\mathrm{GT})_{2}$ & no specific signal & $55-62$ \\
\hline 16 & AF467829 & Boms I 6 (Bo-D46) & $(\mathrm{CA})_{10}$ & $42(I I R)$ & 58 \\
\hline 17 & EU489758 & Boms 17 & $(\mathrm{TG})_{13}$ & 44(IIR) & 58 \\
\hline 18 & AF467828 & Boms / 8 & $(\mathrm{CA})_{13}$ & - & \\
\hline 19 & EU489759 & Boms 19 & $\mathrm{CAAA}(\mathrm{CA})_{10}$ & - & \\
\hline 20 & EU489760 & Boms20 & $(\mathrm{GT})_{13+}$ & $8(I L) 2$ signals & 58 \\
\hline 21 & AF467827 & Boms2I & GTGG(GT) ${ }_{13}$ ATGT & 73(IVL) & 58 \\
\hline 22 & DQ078248 & Boms22 & $\mathrm{CAT}(\mathrm{CA})_{7}(\mathrm{TA})_{3} \mathrm{TT}(\mathrm{TA})_{5}$ & $5(\mathrm{IL})$ & 58 \\
\hline 23 & EU48976I & Boms23 & $(\mathrm{CA})_{12}$ & $3(\mathrm{IL})$ & 58 \\
\hline 24 & EU489762 & Boms24 & $(\mathrm{GT})_{12}$ & 64(IIIR) & 58 \\
\hline 25 & AF467826 & Boms 25 & $(\mathrm{GT})_{12}$ & 30(IIL), 97\& I00(VR) & $58 / 62$ \\
\hline 26 & EU489763 & Boms26 & $(\mathrm{GT})_{8} \mathrm{AT}(\mathrm{GT})_{2}$ & $26(I I L)$ & 58 \\
\hline 27 & AF467825 & Boms27 (Bo-D52) & $(\mathrm{GA})_{14}$ & 83(IVR) & 58 \\
\hline 28 & EU489764 & Boms28 & $(\mathrm{CA})_{12} \mathrm{CT}(\mathrm{CA})_{5}(\mathrm{GA})_{12} \mathrm{GG}(\mathrm{GA})_{11}$ & - & \\
\hline 29 & AF467824 & Boms29 & $(\mathrm{GT})_{10}$ & - & \\
\hline 30 & AF467823 & Boms30 & $(\mathrm{GT})_{17}$ & $5-6(\mathrm{IL})$ & 58 \\
\hline 31 & DQ078249 & Boms3l & $(\mathrm{GT})_{4} \mathrm{GC}(\mathrm{GT})_{6} \mathrm{GC}(\mathrm{GT})_{2}$ & 63\&65(IIIR) & 58,62 \\
\hline 32 & EU489765 & Boms32 & $(\mathrm{CA})_{14}$ & - & \\
\hline 33 & EU489766 & Boms33 & $(\mathrm{CA})_{2} \mathrm{TA}(\mathrm{CA})_{9}$ & no signal & $55-58$ \\
\hline 34 & EU489767 & Boms34 & $(\mathrm{CA})_{3} \mathrm{CTA}(\mathrm{CA})_{8}$ & 86(IVR) & 58 \\
\hline 35 & EU489768 & Boms35 & $(\mathrm{CA})_{48}$ & - & \\
\hline 36 & EU489769 & Boms36 & $(\mathrm{CA})_{24}$ & - & \\
\hline 37 & EU489770 & Boms37 & $(\mathrm{TG})_{4} \mathrm{G}(\mathrm{TG})_{3}$ & - & \\
\hline 38 & EU48977I & Boms38 & $(\mathrm{GT})_{10} \mathrm{AT}(\mathrm{GT})_{6}$ & - & \\
\hline 39 & EU489772 & Boms4l & $\mathrm{GTAT}(\mathrm{GT})_{8} \mathrm{GCGTGA}(\mathrm{GT})_{4}$ & - & \\
\hline 40 & EU489773 & Boms42 & $(\mathrm{AT})_{3} \mathrm{CC}(\mathrm{GT})_{3}(\mathrm{AT})_{3}(\mathrm{GT})_{14} \mathrm{GAGT}$ & - & \\
\hline 41 & EU489774 & Boms43 & $(\mathrm{CA})_{18} \mathrm{C}(\mathrm{CA})_{3}$ & - & \\
\hline 42 & EU489775 & Boms45 & $\operatorname{TAA}(\mathrm{CAA})_{6}$ & - & \\
\hline 43 & EU489776 & Boms47 & $(\mathrm{AG})_{12} \mathrm{TG}(\mathrm{AG})_{8}(\mathrm{TG})_{3}(\mathrm{AG})_{10}$ & - & \\
\hline 44 & EU489777 & Boms48 & $(\mathrm{TC})_{5} \mathrm{C}_{8} \mathrm{G}(\mathrm{CT})_{4} \mathrm{C}_{5} \mathrm{G}(\mathrm{CT})_{5} \mathrm{C}_{5} \mathrm{G}(\mathrm{CT})_{6} \mathrm{CCTCG}(\mathrm{CT})_{8}$ & - & \\
\hline 45 & EU489778 & Boms49 & $(\mathrm{CA})_{3} \mathrm{CT}(\mathrm{CA})_{3} \mathrm{CT}(\mathrm{CA})_{3} \mathrm{CT}(\mathrm{CA})_{9}$ & - & \\
\hline 46 & EU489779 & Boms50 & $(\mathrm{GA})_{18} \mathrm{~N}_{4}(\mathrm{GA})_{2} \mathrm{G}_{4}(\mathrm{GA})_{2} \mathrm{G}_{4}(\mathrm{GA})_{14} \mathrm{CA}(\mathrm{GA})_{2} \mathrm{TA}(\mathrm{GA})_{5}$ & - & \\
\hline 47 & EU489780 & Boms53 & $\mathrm{T}_{8} \mathrm{GT}_{10} \mathrm{GT}_{7} \mathrm{CGT}_{9} \mathrm{GT}_{6}$ & - & \\
\hline 48 & EU48978I & Boms55 & $(\mathrm{AG})_{13} \mathrm{GG}(\mathrm{AG})_{3} \mathrm{GC}(\mathrm{AG})_{8}$ & - & \\
\hline 49 & EU489782 & Boms58 & $\mathrm{A}_{6} \mathrm{CA}_{3} \mathrm{GCA}_{6} \mathrm{TA}_{5} \mathrm{CA}_{5}$ & - & \\
\hline 50 & DQ078250 & Boms59 & $\mathrm{TGTA}(\mathrm{TG})_{10}$ & - & \\
\hline 51 & DQ07825I & Boms60 & $\begin{array}{c}(\mathrm{CAAA})_{2} \\
\mathrm{~A}_{6} \mathrm{CA}_{3} \mathrm{GCA}_{6} \mathrm{TA}_{5} \mathrm{CA}_{4} \mathrm{~N}_{26} \mathrm{~A}_{2} \mathrm{GA}_{9} \mathrm{CGA}_{4}\end{array}$ & - & \\
\hline 52 & DQ078252 & Boms6l & $\mathrm{T}_{23} \mathrm{G}_{2} \mathrm{~T}_{3} \mathrm{GT}_{3} \mathrm{GT}_{2} \mathrm{GTAAT}_{4} \mathrm{C}_{2} \mathrm{~T}_{5} \mathrm{CTGT}_{5}$ & - & \\
\hline 53 & EU489783 & Boms62 & $\mathrm{A}_{11} \mathrm{CA}_{1 /} \mathrm{CATCACA}_{4} \mathrm{GA}_{2} \mathrm{GA}_{8}$ & - & \\
\hline 54 & EU489784 & Boms63 & $\mathrm{A}_{3} \mathrm{CA}_{3} \mathrm{CCA}_{18}$ & - & \\
\hline 55 & EU489785 & Boms64 & $\begin{array}{c}\mathrm{CAGA}(\mathrm{CA})_{2} \mathrm{C}(\mathrm{CA})_{4} \mathrm{~N}_{12}(\mathrm{CA})_{4} \mathrm{C}(\mathrm{CA})_{2} \\
(\mathrm{CA})_{5} \mathrm{C}(\mathrm{CA})_{4} \mathrm{C}(\mathrm{CA})_{4} \mathrm{ACACC}(\mathrm{CA})_{3} \mathrm{C}(\mathrm{CA})_{3}\end{array}$ & - & \\
\hline 56 & EU489786 & Boms68 & $\mathrm{T}_{8}$ & - & \\
\hline
\end{tabular}


Table I: Microsatellite loci motif and in situ localization to polytene chromosomes (Continued)

\begin{tabular}{ccccc}
\hline 57 & EU489787 & Boms69 & $(\mathrm{A} / \mathrm{G} \mathrm{TT})_{4} \mathrm{~N}_{4} \mathrm{~T}_{7}(\mathrm{CTT})_{2} \mathrm{AGT}_{4} \mathrm{CA}_{2} \mathrm{~T}_{4} \mathrm{GT}_{4}$ & - \\
58 & EU489788 & Boms70 & (GT)-rich & - \\
\hline
\end{tabular}

Boms 1-34: Microsatellite loci isolated from total, small-insert DNA libraries

Boms35-70: Microsatellite loci isolated from enriched libraries

$\mathrm{T}$ : annealing temperature for in situ hybridization

$(-)$ : not tested

$\mathrm{N}$ : bases that do not present any motif

results can be attributed to differences in isolation strategies.

\section{In situ hybridization to polytene chromosomes}

Cytological analysis of $B$. oleae has revealed five chromosomes (10 polytene arms) and a heterochromatic mass, corresponding to the five autosomes and the sex chromosomes, respectively (for a review see [21]). Well-defined polytene maps have been produced, providing the opportunity for a cytologic localization of molecular markers on the chromosomes.

Twenty of the isolated microsatellite clones were in situ hybridised to the salivary gland polytene chromosomes of B. oleae, in order to identify their chromosomal localization. At hybridisation temperature of $58^{\circ} \mathrm{C}$, sixteen of the microsatellite probes gave specific signals (Table 1) and 13 of them mapped to unique chromosome loci. Clone Boms20 hybridised to two neighbouring bands of the same chromosome region, Boms31 hybridised to two regions on the same chromosome arm, while Boms 25 mapped to three regions on two chromosome arms (Table 1, Fig. 1) [Note that microsatellite loci and clones' names are written in italics whereas microsatellite markers' names are written in regular font]. These microsatellite clones gave the same multiple hybridisation pattern even at the higher hybridisation temperature of $62^{\circ} \mathrm{C}$. Chromosome localization was not possible for four of the microsatellite probes, although tested at several hybridisation temperatures. Lack of hybridization signal can be attributed either to insufficient hybridization due to small probe length or to the fact that these clones may lie in heterochromatic regions (such as sex chromosomes or centromeric regions). Boms 33 gave no detectable signal, while the remaining three gave multiple signals.

The thirteen microsatellites that uniquely mapped to the polytene chromosomes of $B$. oleae are dispersed on seven polytene arms, establishing genetic markers for all five autosomes. Table 1 summarizes the microsatellite hybridization sites and Figure 1 schematically presents the relative positions of the hybridization signals to the polytene chromosome arms of $B$. oleae together with previously described markers [21]. Hybridization signals are presented in Figure 2.

Although their number is small, they enrich the already existing cytological map and are the basis for a low-reso- lution cytogenetic map that will facilitate future genome projects of the species. It is encouraging that these thirteen markers are dispersed in seven of the ten chromosome arms (except IR, IIIL, VL). However, our in situ hybridization data are still limited to support a claim of a uniform distribution of microsatellite loci in the olive fly genome.

\section{Development of microsatellite markers}

Unique sequences flanking each repeat array were used to design PCR primer pairs for the amplification of 42 microsatellites. Thirty-one primer pairs amplified a product of the expected size, as revealed by agarose gel electrophoresis (Table 2). Subsequently, all primer pairs that amplified a specific band were used for the genotyping of 20 individual wild flies (from Greece and Cyprus) and/or up to 37 individuals of a laboratory strain. In addition, 19 C. capitata microsatellite markers (Stratikopoulos et al., submitted) that cross-amplified in the olive fly were used, raising the total number of functional primer pairs to 50 (Table 2). In total, 37 primer pairs ( 29 designed for the olive fly and eight for the medfly) amplified a polymorphic and easily scorable PCR product, while eight pairs amplified a monomorphic one. The five remaining primer pairs generated PCR products that were not easily scored (shuttered or multiple bands or faint signal).

The mean allele number per locus was 4.63 for natural populations and 3.14 for laboratory strains (monomorphic loci excluded), demonstrating their usefulness in population analyses of the species. Conformation to HWE was tested for 26 loci for natural populations and 19 loci for laboratory strains, according to $\mathrm{G}^{2}$ criterion, at a significance level of $5 \%$. Only five deviations were observed due to homozygosity excess, which can be attributed to small sample size or to the presence of null alleles (Table 2).

\section{Cross - species amplification in Tephritidae}

The 29 primer pairs designed for the olive fly and proved polymorphic were tested in a pooled mix of five flies from each one of 11 Tephritidae species. Twenty-six of them amplified a specific DNA fragment, at least in one of the species examined. Four species belong to Bactrocera ( $B$. correcta, B. cucurbitae, B. dorsalis and B. tryoni), four to Anastrepha (A. fraterculus, A. ludens, A. serpetina and A. striata), two to Ceratitis (C. capitata and C. fasciventris) and one belongs to Rhagoletis (R. cerasi) (Tables 3 and 4). 

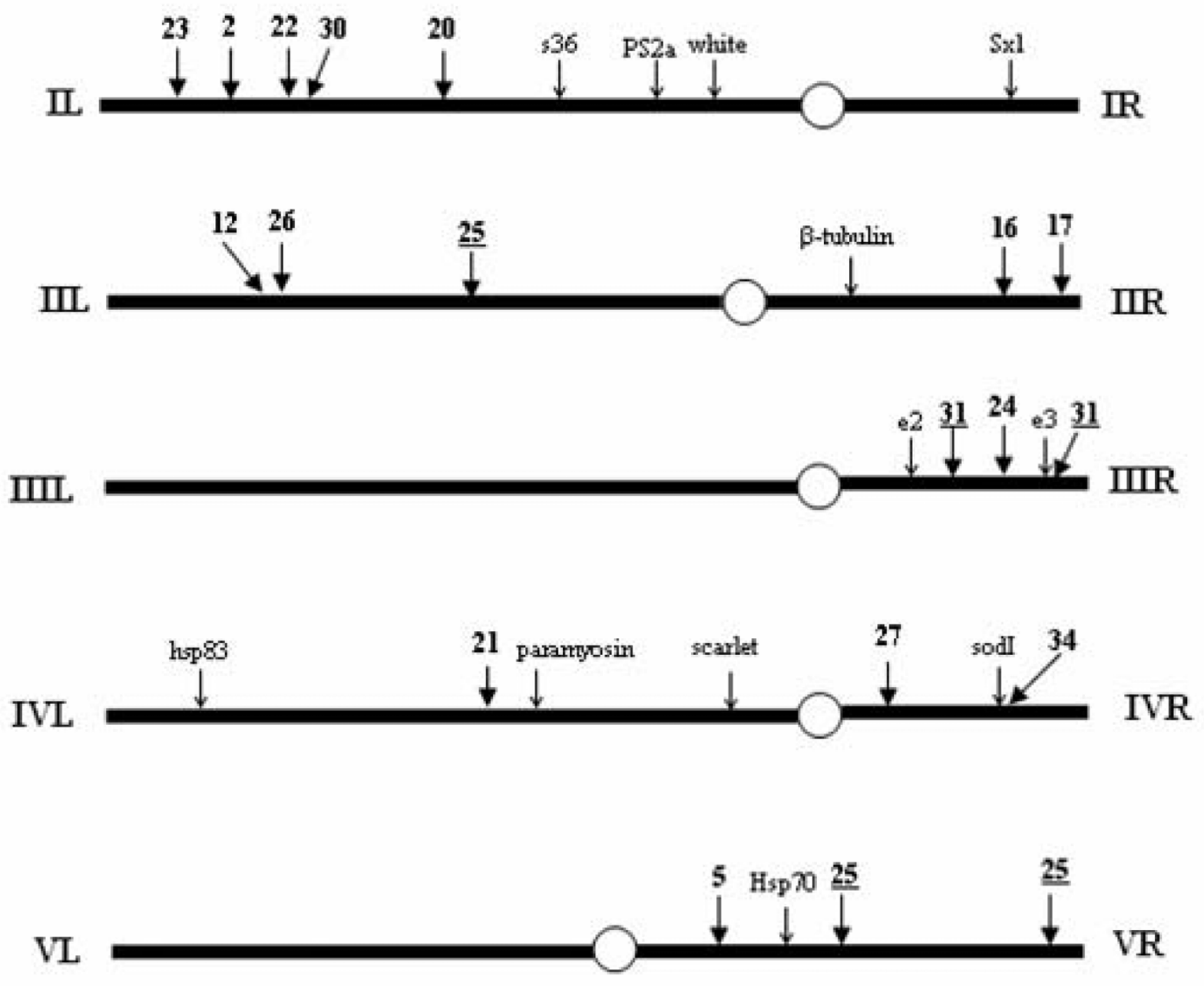

\section{Figure I}

Schematic representation of the in situ localization of microsatellite markers on the polytene chromosomes of Bactrocera oleae. Arrows that originate from numbers in bold stand for the Boms microsatellite markers. Underlined numbers refer to microsatellite markers that give multiple signals. All other arrows refer to previously mapped loci [Zambetaki et al 1999].

A total of 113 PCR products were amplified. The species with the highest degree of amplification was B. tryoni (19/ 29), while with the lowest was Rhagoletis cerasi (8/29). As expected, the highest percentage of amplification was inside Bactrocera, with a mean of $49.1 \%$. Ceratitis presented the next higher amplification degree (34.5\%), followed by Rhagoletis and Anastrepha (27.6\% and 24.1\%, respectively) (Table 4 and Figure 3-1). It is worth mentioning that $B$. cucurbitae exhibited very low amplification rate, similar to that of Anastrepha. Finally, C. capitata presented substantially lower degree of amplification than $C$. fasciventris.
The majority of PCR products had similar size (less than $\sim 50$ bp difference, as estimated by agarose gel electrophoresis) with those obtained in B. oleae (about $76 \%$ ). Still, the highest degree of PCR product size conservation was inside Bactrocera (84.2\%), although Ceratitis showed a comparable percentage (80\%). Anastrepha and Rhagoletis presented significantly lower values $(64.3 \%$ and $50 \%$, respectively) (Table 4 and Figure 3-2). Surprisingly, $B$. cucurbitae showed very low size conservation (66.7\%), comparable to that of Anastrepha, implying that the low amplification value mentioned before may not be a PCR artefact. This in not the case in C. capitata, since size con- 

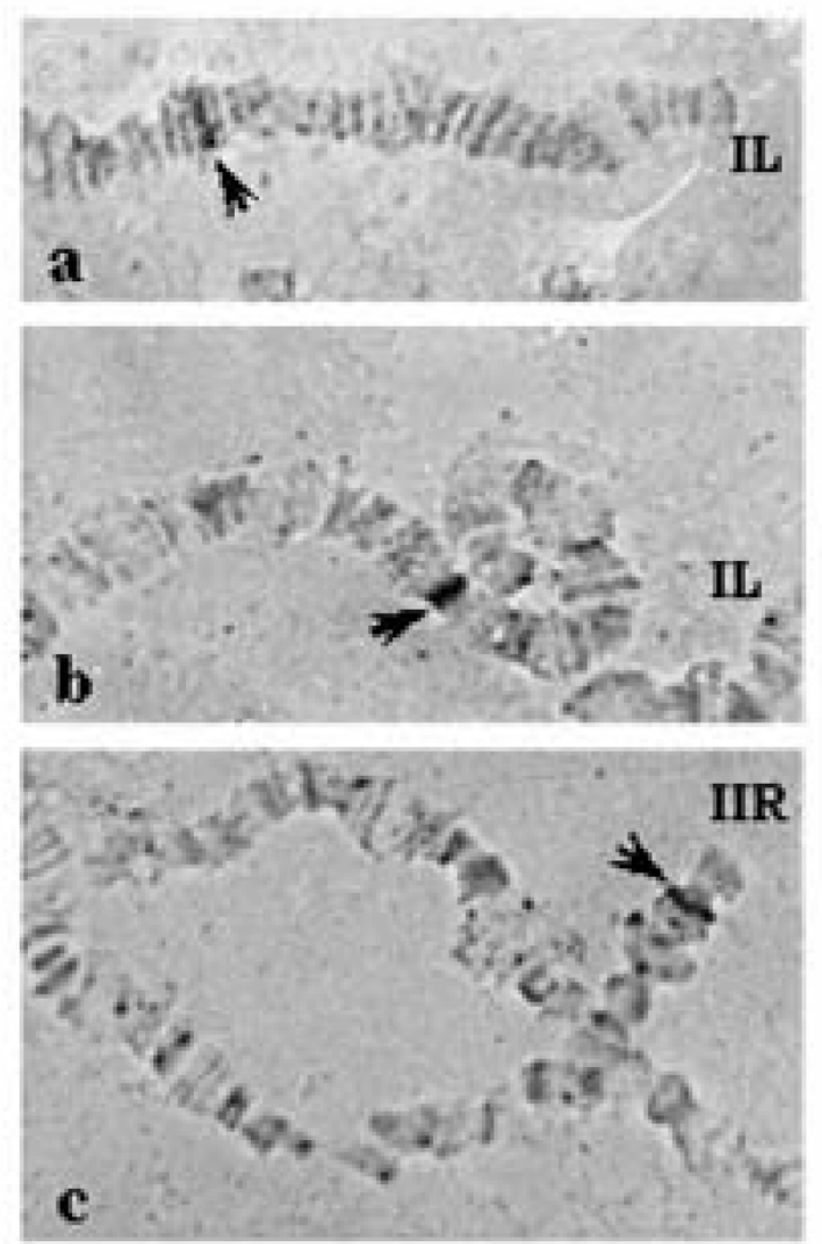
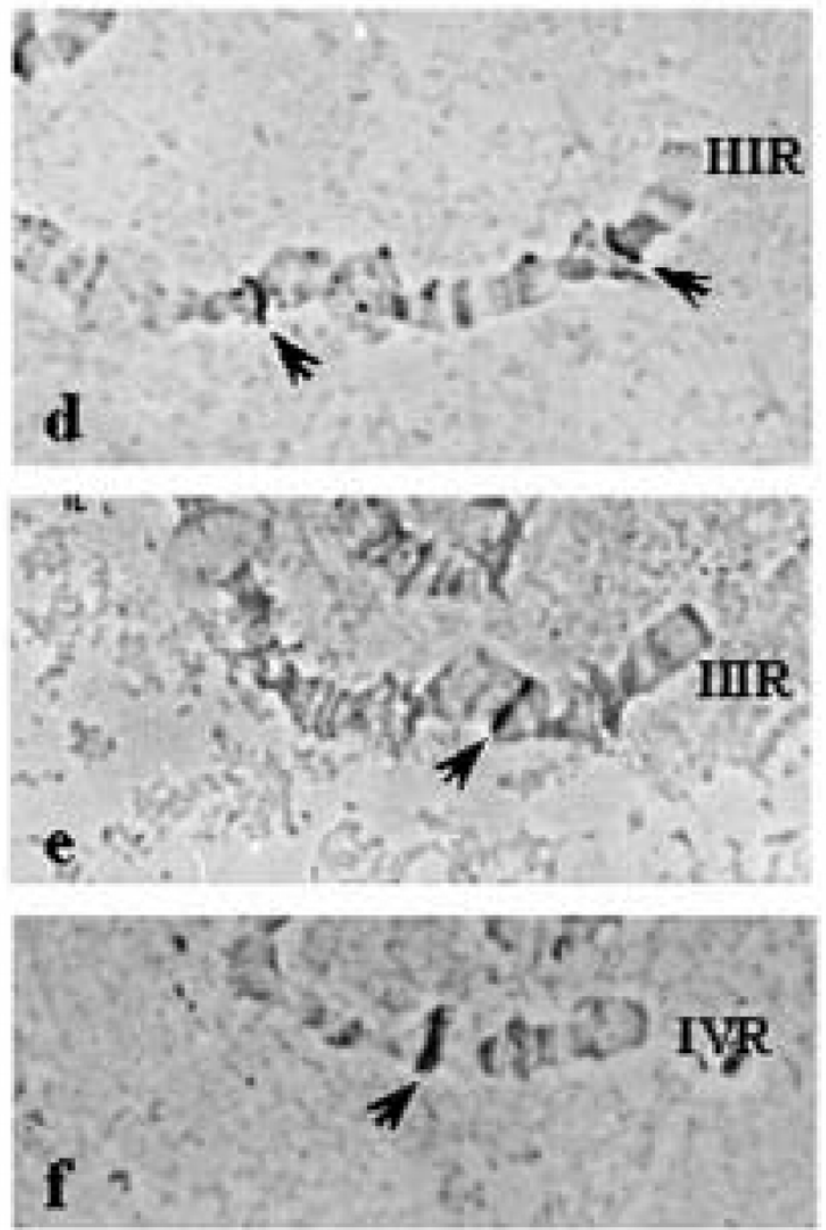

\section{Figure 2}

In situ hybridization of several microsatellite probes on the salivary gland polytene chromosomes of Bactrocera oleae. a: Boms23; b: Boms2; c: Boms 17; d: Boms31; e: Boms24; f: Boms34. Arrows indicate the hybridization signals.

servation is very high $(87.5 \%)$. This value is higher than that of C. fasciventris and comparable to that of Bactrocera, suggesting that medfly's low amplification value is more likely a PCR artefact.

\section{Analysis of cross-species amplification products}

Amplification of a band of expected size does not necessarily mean that the expected microsatellite motif is also present. To evaluate the degree of motif conservation, 31 of the reactions that produced a specific band were subcloned and sequenced. We focused on PCR products of similar to the expected size and distributed in as many species as possible. Twenty-seven of the amplification products harboured a repeat motif, 25 of which contained the same as that of B. oleae. Six of the products harboured new motifs (instead of or in addition to the expected ones) (Table 5).
Nineteen (of the 31) sequencing reactions were performed in Bactrocera. The presence of a microsatellite motif in 18 of them (16 of which had the expected motif), demonstrates their potential in the analysis of other Bactrocera species. Results from other genera are encouraging, although preliminary. In Ceratitis, for example, four sequencing reactions were performed, three of which exhibited the expected motif. In Anastrepha, five sequencing reactions were performed, all of which exhibited a microsatellite motif with four cases possessing the expected one (however, they all refer to the same locus in four different species). Finally, in Rhagoletis, three sequencing reactions were performed, one of which exhibited a microsatellite repeat of the expected motif. These results are summarized in Tables 4 and 5 and demonstrate the potential utility of these markers in the analysis of Tephritidae genera other than Bactrocera. 
Table 2: Microsatellite markers' characteristics and genetic variability

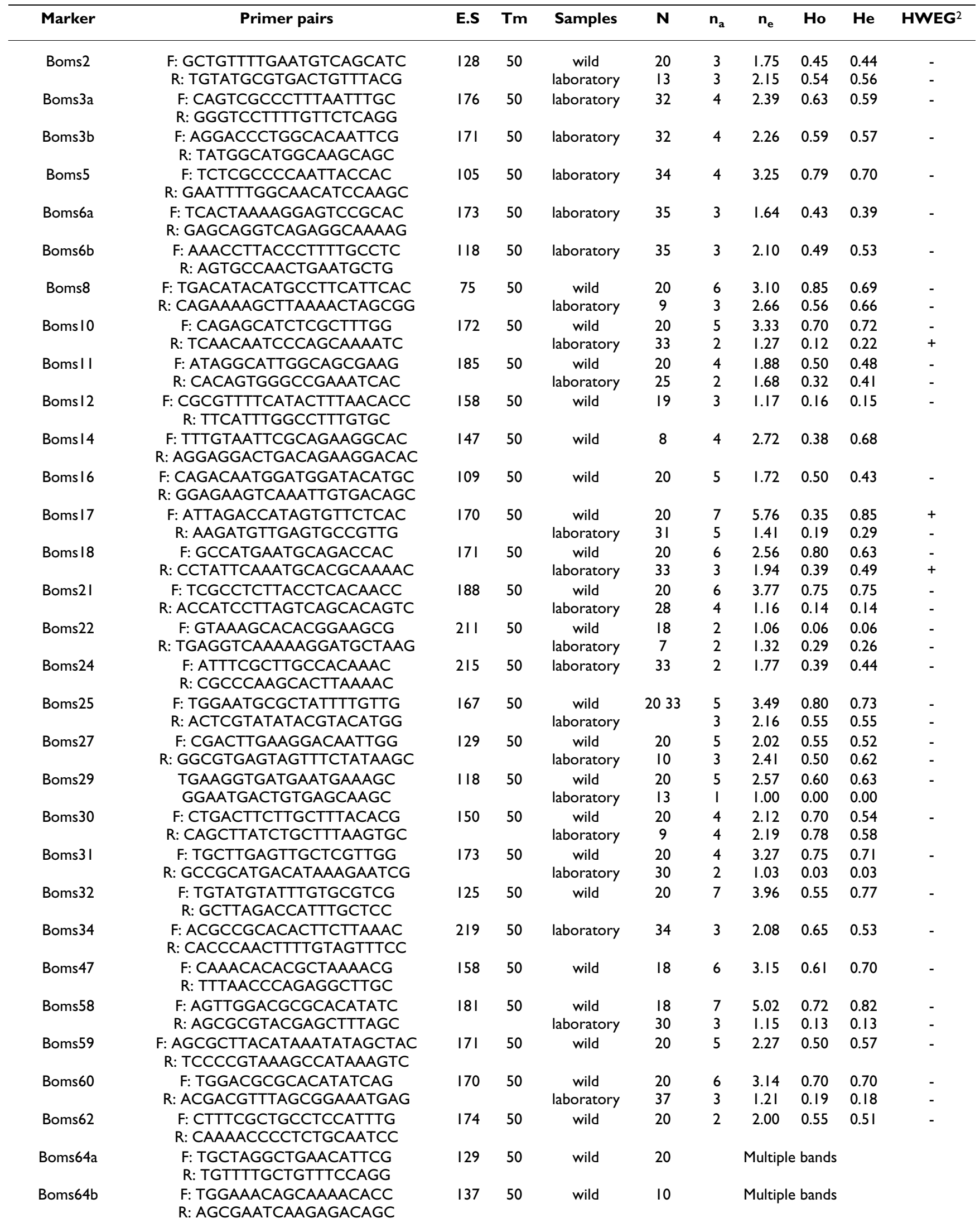


Table 2: Microsatellite markers' characteristics and genetic variability (Continued)

\begin{tabular}{|c|c|c|c|c|c|c|c|c|c|}
\hline Medflymic9 & Stratikopoulos et al., submitted & 50 & wild & 8 & 3 & 2.42 & 0.88 & 0.63 & \\
\hline Medflymic|42 & $>$ & 50 & wild & 9 & \multicolumn{4}{|c|}{ monomorphic } & \\
\hline Medflymic|49 & $>>$ & 50 & wild & 8 & \multicolumn{4}{|c|}{ monomorphic } & \\
\hline Medflymic I 50 & $>$ & 50 & wild & 8 & 3 & 2.03 & 0.50 & 0.54 & \\
\hline Medflymic I5I & $>$ & 50 & wild & 20 & 5 & 2.66 & 0.35 & 0.64 & + \\
\hline Medflymic I 52 & $>>$ & 50 & wild & 20 & 6 & 5.00 & 0.40 & 0.82 & + \\
\hline Medflymic I 53 & $>>$ & 50 & wild & 20 & 3 & 2.24 & 0.40 & 0.57 & - \\
\hline Medflymic I 54 & $>>$ & 50 & wild & 10 & \multicolumn{4}{|c|}{ monomorphic } & \\
\hline Medflymic I 57 & $>>$ & 50 & wild & 10 & \multicolumn{4}{|c|}{ monomorphic } & \\
\hline Medflymic 158 & $>>$ & 50 & wild & 8 & 3 & 2.25 & 0.63 & 0.59 & \\
\hline Medflymic 163 & $>>$ & 50 & wild & 10 & \multicolumn{4}{|c|}{ monomorphic } & \\
\hline Medflymic22 & $>>$ & 55 & wild & 20 & \multicolumn{4}{|c|}{ Multiple bands } & \\
\hline Medflymic23 & $>>$ & 55 & wild & 20 & \multicolumn{4}{|c|}{ monomorphic } & \\
\hline Medflymic29 & $>>$ & 55 & wild & 20 & \multicolumn{4}{|c|}{ Multiple bands } & \\
\hline Medflymic40 & $>>$ & 55 & wild & 20 & \multicolumn{4}{|c|}{ Multiple bands } & \\
\hline Medflymic6I & $>>$ & 55 & wild & 20 & 4 & 2.32 & 0.45 & 0.58 & - \\
\hline Medflymic64 & $>$ & 55 & wild & 20 & \multicolumn{4}{|c|}{ monomorphic } & \\
\hline Medflymic72 & $>>$ & 55 & wild & 20 & \multicolumn{4}{|c|}{ monomorphic } & \\
\hline Medflymic 109 & $>>$ & 55 & wild & 20 & 2 & 1.05 & 0.05 & 0.05 & - \\
\hline & $\begin{array}{l}\text { Mean wild (monomorphic excluded) } \\
\text { Mean laboratory (monomorphic excluded) }\end{array}$ & & & $\begin{array}{l}19.5 \\
26.5\end{array}$ & $\begin{array}{l}4.63 \\
3.14\end{array}$ & $\begin{array}{l}2.74 \\
1.90\end{array}$ & $\begin{array}{l}0.53 \\
0.44\end{array}$ & $\begin{array}{l}0.57 \\
0.44\end{array}$ & \\
\hline
\end{tabular}

\section{E.S: Expected size}

Tm: PCR annealing temperature

$\mathrm{N}$ : sample size

$\mathrm{n}_{\mathrm{a}}$ : actual number of alleles; $\mathrm{n}_{\mathrm{e}}$ : effective number of alleles

Ho: heterozygosity observed; He: heterozygosity expected

$(-)$ : in HWE; (+): out of HWE

Mean number of uninterrupted repeats was measured only in cases where the expected motif was present in cross-species amplification products (Table 4). In seventeen cases within Bactrocera (regarding seven microsatellite loci), the mean number of uninterrupted repeats was 9.8 for B. oleae and 5.4 for the other Bactrocera species. Same analysis for three PCR products (regarding three microsatellites) in Ceratitis gave a mean of 9.0 and 5.0 uninterrupted repeats for $B$. oleae and Ceratitis, respectively. Although sequencing data are still limited, it is obvious that microsatellites tend to present longer arrays in the species in which they were isolated from. This has been described in a variety of species, such as Drosophila $[40,46]$ and primates [47], and has been attributed to the fact that microsatellites can evolve directionally and at different rates in closely related species.

\section{Sequencing analysis and phylogenetic comparisons}

Although we did not perform a phylogenetic analysis, it seems that measures of cross-species amplification (e.g., percentages of functional primers and expected size of PCR products) are indicative of the phylogenetic history of these species. Our results support the notion that three of the Bactrocera species are very close to $B$. oleae, while the fourth (B. cucurbitae) seems to be more distant (Table 4, Figure 3). Also, Ceratitis seems to be more closely related to Bactrocera than Anastrepha and Rhagoletis seems to be the most distantly related genus to Bactrocera. These results perfectly replicate the exact same relationships observed in the most recent phylogenetic analysis of these species based on mtDNA sequencing data [48]. Secondarily, they are also supported by several other studies from different insect species based on alignment of mitochondrial $16 \mathrm{~S}$ rDNA sequences $[49,50]$ and $18 \mathrm{~S}$ rDNA sequences [51], which show that Bactrocera is more closely related to Ceratitis, and closer to Anastrepha than it is to Rhagoletis. In addition, we also performed sequencing alignments of a few cross-species amplification products of some of our markers (data not shown). In all cases, the different species were clustered to their respective genera with high bootstrap values. Although these data are very limited, they come from dispersed regions of nuclear DNA which gives significant value to phylogenetic analyses. There are studies supporting that microsatellite data can shed light to phylogenetic relationships among closely related taxa [52-54]. Sequencing analysis of more microsatellite markers can probably reveal complex phylogenetic relationships among different Tephritidae species, especially in cases of species complexes.

\section{Polymorphism of cross-species microsatellite markers}

Presence of a microsatellite motif does not necessarily mean that these loci can be used as genetic markers. Nineteen microsatellite markers developed in the medfly crossamplified in the olive fly (Table 2). The fact that eight of them were polymorphic in a relative small sample (twenty wild flies) confirms the possible utility of the markers presented here in the analysis of other Tephritidae species. 
Table 3: Cross-species amplification of Bactrocera oleae microsatellite markers in other Tephritidae species

\begin{tabular}{|c|c|c|c|c|c|c|c|c|c|c|c|c|}
\hline \multirow{2}{*}{$\begin{array}{l}\text { Species } \\
\text { Markers }\end{array}$} & \multicolumn{5}{|c|}{ Bactrocera } & \multicolumn{4}{|c|}{ Anastrepha } & \multicolumn{2}{|c|}{ Ceratitis } & \multirow{2}{*}{$\begin{array}{c}\text { Rhagoletis } \\
R c\end{array}$} \\
\hline & Bo & $B c u$ & $B c o$ & $B d$ & $B t$ & $A f$ & $A l$ & Astr & Aser & $C_{c}$ & $C f$ & \\
\hline Boms2 & 150 & 400 & 400 & & & $\mathrm{Sm}$ & $\begin{array}{l}450 / \\
\mathrm{Sm}\end{array}$ & Sm & $\mathrm{Sm}$ & 200 & $200 f$ & Sm \\
\hline Boms3a & 210 & 210 & 210 & 210 & 230 & & & & & 190 & 190 & 500 \\
\hline Boms3b & 200 & $x$ & 220 & 200 & 210 & $\mathrm{Sm}$ & Sm & Sm & $x$ & 150 & & 200 \\
\hline Boms5 & 110 & 500 & & 700 & 130 & & & & 300 & & & \\
\hline Boms6a & $\begin{array}{l}150 / \\
400\end{array}$ & $\begin{array}{l}350 / \\
\mathrm{Sm}\end{array}$ & & 350 & $\begin{array}{l}300 / \\
500\end{array}$ & & & $\mathrm{Sm}$ & $\mathrm{Sm}$ & & 600 & $\begin{array}{c}200 / \\
300\end{array}$ \\
\hline Boms6b & 150 & & & & & & & & & & $\begin{array}{l}\text { I50f/ } \\
200\end{array}$ & \\
\hline Boms8 & 75 & & & & & & & & & & 200 & \\
\hline Boms 10 & 200 & & & 180 & 200 & & $\begin{array}{l}180 / \\
\mathrm{Sm}\end{array}$ & & $\begin{array}{l}120 \mathrm{f} / \\
150 \mathrm{f}\end{array}$ & 150 & $\begin{array}{l}200 / \\
300\end{array}$ & 300 \\
\hline BomsII & 200 & Sm & 220 & $\mathrm{Sm}$ & Sm & $\mathrm{Sm}$ & $\mathrm{Sm}$ & Sm & $\mathrm{Sm}$ & $\mathrm{Sm}$ & $\mathrm{Sm}$ & 500 \\
\hline Boms 12 & 200 & & & & & & & Sm & $\mathrm{Sm}$ & & & \\
\hline Boms I4 & 150 & & 150 & & 150 & 300 & & Sm & $\mathrm{Sm}$ & & & \\
\hline Boms I 6 & 100 & & & 100 & 100 & & & & & & & \\
\hline Boms 18 & $17 \mid$ & & 170 & 170 & 190 & $\mathrm{Mb}$ & $\mathrm{Mb}$ & $\mathrm{Mb}$ & $\mathrm{Mb}$ & 300 & 300 & \\
\hline Boms2l & 188 & 190 & 180 & & 180 & & & & & & & \\
\hline Boms 22 & 210 & & & & $500 f$ & & & & & & & \\
\hline Boms24 & 200 & & 250 & 250 & 250 & & & & & & & \\
\hline Boms 27 & 130 & & 130 & 130 & 130 & $\mathrm{Sm}$ & $\mathrm{Sm}$ & $\mathrm{Sm}$ & $\mathrm{Sm}$ & $\mathrm{Sm}$ & $\begin{array}{l}150 / \\
\mathrm{Mb}\end{array}$ & Sm \\
\hline Boms29 & 120 & & & & & & & & & & & \\
\hline Boms30 & 150 & 150 & 150 & 150 & 150 & & $\mathrm{Mb}$ & 130 & 130 & 110 & 110 & 110 \\
\hline Boms3I & 170 & & 120 & 170 & 170 & 500 & $\begin{array}{l}120 \mathrm{f} / \\
300 / \\
500 / \\
600\end{array}$ & $120 f$ & $\begin{array}{l}120 \mathrm{f} / \\
400 / \\
500 / \\
700\end{array}$ & & 800 & $450 f$ \\
\hline Boms32 & 150 & 150 & & & & & & & & & & \\
\hline Boms34 & 200 & & 200 & $x$ & 200 & & & & & & & \\
\hline Boms58 & 180 & & 400 & $\begin{array}{l}150 \mathrm{f} / \\
180 \mathrm{f}\end{array}$ & $\begin{array}{l}150 \mathrm{f} / \\
180 \mathrm{f}\end{array}$ & 400 & $\begin{array}{c}400 / \\
500\end{array}$ & 500 & 400 & $\mathrm{Sm}$ & $\mathrm{Sm}$ & Sm \\
\hline Boms 60 & 170 & $150 f$ & 170 & 170 & 170 & 150 & 150 & 150 & 150 & 170 & $\begin{array}{l}250 / \\
\mathrm{Mb}\end{array}$ & 150 \\
\hline Boms62 & 174 & 200 & 160 & 200 & 180 & $\begin{array}{l}160 / \\
\mathrm{Mb}\end{array}$ & $\begin{array}{l}160 / \\
\mathrm{Mb}\end{array}$ & $\begin{array}{l}160 / \\
\mathrm{Mb}\end{array}$ & $\begin{array}{l}160 / \\
\mathrm{Mb}\end{array}$ & 200 & 160 & \\
\hline Boms64a & 150 & & & & & & & $\begin{array}{c}300 / \\
450\end{array}$ & 500 & & & \\
\hline
\end{tabular}

Numbers in columns indicate PCR product size, as revealed by agarose gel electrophoresis

Sm: smear; f: faint band; Mb: multiple bands

Bo: B. oleae; Bco: B. correcta; Bcu: B. cucurbitae; Bd: B. dorsalis; Bt: B. tryoni; Cc: C. capitata; Cf: C. fasciventris; Af: A. fraterculus; Al: A. ludens; Aser: A.

serpentina; Astr: A. striata; Rc: R. cerasi

\section{Conclusion}

Since their discovery, microsatellite markers have been particularly useful in population and genetic analyses, mainly due to their high degree of polymorphism. Their significance is even greater in organisms like the olive fly, where the lack of morphological markers makes classical genetic analysis practically impossible. The interest in olive fly's genetics is not only theoretical, since modern genetic and molecular tools have benefited several operational SIT programmes, particularly those where GSSs are involved [15]. The observed polymorphism of the developed microsatellite markers (both in laboratory and natural populations) guarantees their utility in genetic and population analyses. A subset of these markers has already been successfully used in previous population studies $[36,19]$. The existence of well-described polytene chromosomes in the olive fly [21] and the possibility of cytological localization of molecular markers by in situ hybridisation provide a powerful method to link the genetic and molecular information of an organism. The existence of defined polytene chromosomes in other Diptera $[55,56]$ also offers the opportunity to establish syntenic linkages and to study the evolutionary relationships of separate chromosomal segments $[57,21]$. Cross-species amplification of the developed markers to other Tephritidae demonstrates their potential utility in those species. 
Table 4: Conservation of Bactrocera oleae microsatellite markers in Tephritidae

\begin{tabular}{|c|c|c|c|c|c|}
\hline $\begin{array}{l}\text { Species/ } \\
\text { Genera }\end{array}$ & Functional primer pairs & Expected size & Presence of SSR motif & $\begin{array}{l}\text { Presence of the expected } \\
\text { motif }\end{array}$ & $\begin{array}{l}\text { Mean number of } \\
\text { uninterrupted repeats }\end{array}$ \\
\hline B. oleae & 29 & 29 & 29 & 29 & $100 \%$ \\
\hline B. correcta & I5/29 (5I.7\%) & $\begin{array}{l}\text { I3/15 (86.7\%) } \\
\text { I3/29 (44.8\%) }\end{array}$ & $6 / 7(85.7 \%)$ & $\begin{array}{l}5 / 6(83.3 \%) \\
5 / 7(71.5 \%)\end{array}$ & $20 / 50(40 \%)$ \\
\hline B. cucurbitae & $9 / 29(31 \%)$ & $\begin{array}{l}6 / 9(66.7 \%) \\
6 / 29(20.7 \%)\end{array}$ & $2 / 2(100 \%)$ & $\begin{array}{l}2 / 2(100 \%) \\
2 / 2(100 \%)\end{array}$ & II/27 (40\%) \\
\hline B. dorsalis & I 4/29 (48.3\%) & $\begin{array}{l}\text { I2/14 (85.7\%) } \\
\text { I2/29 (4I.4\%) }\end{array}$ & $4 / 4(100 \%)$ & $\begin{array}{l}4 / 4(100 \%) \\
4 / 4(100 \%)\end{array}$ & $29 / 36(80.5 \%)$ \\
\hline B. tryoni & $19 / 29(65.5 \%)$ & $\begin{array}{l}17 / 19(89.5 \%) \\
17 / 29(58.6 \%)\end{array}$ & $5 / 6(83.3 \%)$ & $\begin{array}{l}5 / 5(100 \%) \\
5 / 6(83.3 \%)\end{array}$ & $32 / 53(60 \%)$ \\
\hline $\begin{array}{l}\text { Bactrocera } \\
\text { genus }\end{array}$ & $57 / 116$ (49.1\%) & $\begin{array}{c}48 / 57(84.2 \%) \\
48 / 116(41.4 \%)\end{array}$ & $17 / 19$ (89.5\%) & $\begin{array}{l}16 / 17(94.1 \%) \\
16 / 19(84.2 \%)\end{array}$ & $92 / 166(55.4 \%)$ \\
\hline A. fraterculus & $5 / 29(17.2 \%)$ & $\begin{array}{c}2 / 5(40 \%) \\
2 / 29(6.9 \%)\end{array}$ & $2 / 2(100 \%)$ & $\begin{array}{l}\mathrm{I} / 2(50 \%) \\
\mathrm{I} / 2(50 \%)\end{array}$ & $8 / 9(88.9 \%)$ \\
\hline A. ludens & $7 / 29$ (24.1\%) & $\begin{array}{l}5 / 7(71.5 \%) \\
5 / 29(17.2 \%)\end{array}$ & $\mathrm{I} / \mathrm{I}(100 \%)$ & $\begin{array}{l}\mathrm{I} / \mathrm{I}(100 \%) \\
\mathrm{I} / \mathrm{I}(100 \%)\end{array}$ & $11 / 9$ (122\%) \\
\hline A. serpentina & $9 / 29(31 \%)$ & $\begin{array}{l}6 / 9(66.7 \%) \\
6 / 29(20.7 \%)\end{array}$ & $\mathrm{I} / \mathrm{I}(100 \%)$ & $\begin{array}{l}\mathrm{I} / \mathrm{I}(100 \%) \\
\mathrm{I} / \mathrm{I}(100 \%)\end{array}$ & $8 / 9(88.9 \%)$ \\
\hline A. striata & $7 / 29$ (24.1\%) & $\begin{array}{l}5 / 7(71.5 \%) \\
5 / 29(17.2 \%)\end{array}$ & I/I (100\%) & $\begin{array}{l}\mathrm{I} / \mathrm{I}(100 \%) \\
\mathrm{I} / \mathrm{I}(100 \%)\end{array}$ & $12 / 9(133 \%)$ \\
\hline Anastrepha genus & $28 / 116$ (24.1\%) & $\begin{array}{l}18 / 28(64.3 \%) \\
18 / 116(15.5 \%)\end{array}$ & $5 / 5$ (100\%) & $\begin{array}{l}4 / 5(80 \%) \\
4 / 5(80 \%)\end{array}$ & $39 / 36$ (108.3\%) \\
\hline C. capitata & $8 / 29(27.6 \%)$ & $\begin{array}{c}7 / 8(87.5 \%) \\
7 / 29(24.1 \%)\end{array}$ & $\mathrm{I} / 2(50 \%)$ & $\begin{array}{l}1 / 1(100 \%) \\
1 / 2(50 \%)\end{array}$ & $2 / 3(66.7 \%)$ \\
\hline C. fasciventris & $12 / 29(4 \mid .4 \%)$ & $\begin{array}{l}9 / 12(75 \%) \\
9 / 29(31 \%)\end{array}$ & $2 / 2(100 \%)$ & $\begin{array}{l}2 / 2(100 \%) \\
2 / 2(100 \%)\end{array}$ & $12 / 24(50 \%)$ \\
\hline Ceratitis genus & $20 / 58(34.5 \%)$ & $\begin{array}{c}16 / 20(80 \%) \\
16 / 58(27.6 \%)\end{array}$ & $3 / 4(75 \%)$ & $\begin{array}{l}3 / 3(100 \%) \\
3 / 4(75 \%)\end{array}$ & I 5/27 (55.5\%) \\
\hline R. cerasi & $8 / 29(27.6 \%)$ & $\begin{array}{l}4 / 8(50 \%) \\
13.8 \%\end{array}$ & I/3 (33.3\%) & $\begin{array}{l}1 / 1(100 \%) \\
1 / 3(33.3 \%)\end{array}$ & $2 / 3(66.7 \%)$ \\
\hline
\end{tabular}

Functional primer pairs: number of primer pairs that cross-amplified successfully; Expected size: number of primer pairs that cross-amplified and produced fragment of the expected size (calculated either in regard to total available primer pairs or in regard to primer pairs that successfully cross-amplified); Presence of SSR motif: number of cross-species amplification products that harboured a microsatellite motif; Presence of the expected motif: number of cross-species amplification products that harboured the expected microsatellite motif (calculated either in regard to total sequencing reactions or in regard to cross-species amplification products that harboured a microsatellite motif); Mean number of uninterrupted repeats: sum and comparison of the number of uninterrupted repeats for primer pairs that cross-amplified and harboured the expected motif. Dividend represents repeats in the new species, while divider stands for number of repeats in B. oleae

Sequencing analysis of several cross-amplified products revealed a varying degree of conservation that declines outside the Bactrocera genus. Such sequencing analyses can also assist the clarification of phylogenetic relationships among different species, particularly in cases of species complexes.

\section{Methods}

\section{Fly culture and stocks}

Field-collected samples: Olive fruits were collected and kept in the laboratory until adult flies emerged. These flies were preserved individually at $-20^{\circ} \mathrm{C}$ until DNA extraction.
Laboratory strain

B. oleae flies used for in situ hybridisation and polymorphism analysis were obtained from the Department of Biology, "Demokritos" Nuclear Research Center, Athens, Greece. In our laboratory the stock was reared on an artificial medium based on yeast hydrolysate, sucrose, egg yolk and water [58-60] at $25 \pm 1^{\circ} \mathrm{C}$ and a $12 \mathrm{~h}$ light: $12 \mathrm{~h}$ dark

cycle.

\section{Construction and screening of total small insert genomic libraries}

Genomic DNA was extracted from adult flies of the laboratory strain as described in [61]. Approximately $3 \mu \mathrm{g}$ of 
Cross - species amplification of $B$. oleae microsatellites in four Tephritidae genera

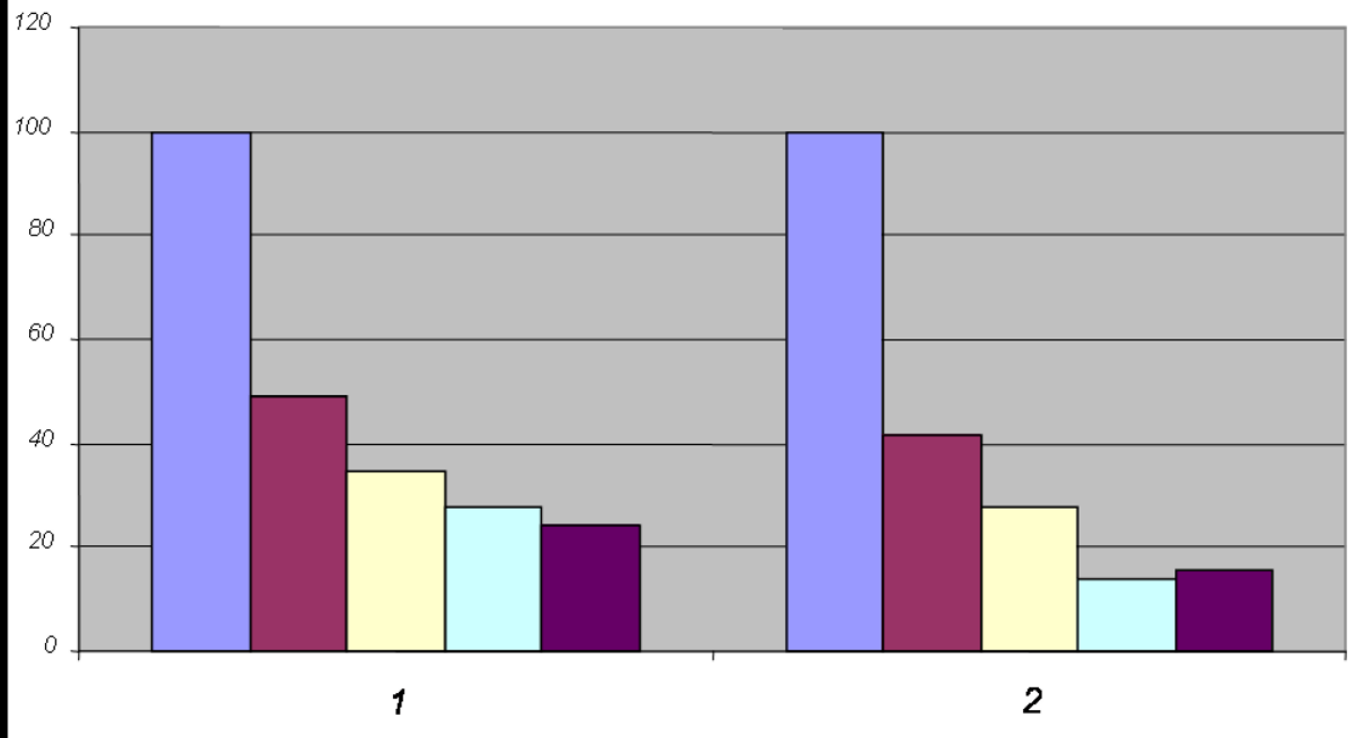

Bactrocera oleae

Bactrocera genus

Ceratitis genus

Rhagoletis genus

Anastrepha genus

Figure 3

Cross-species amplification of Bactrocera oleae microsatellites in four Tephritidae genera. I: Percentage of crossamplified primer pairs. 2: Percentage of primer pairs that produced a fragment of the expected size.

genomic DNA were digested to completion with MboI and digestion products were electrophoresed in $1 \%$ agarose gel (Seakem GTG). Restriction fragments that ranged between $500 \mathrm{bp}$ and $1200 \mathrm{bp}$ were isolated from the gel (Jetquick gel extraction kit, Genomed) and cloned into the BamHI site of plasmid vector pBlueskript II SK (Stratagene). About $10^{4}$ recombinant clones were transferred onto nylon membranes (Hybond-N, Amersham), screened with a mix of radioactively labeled $(\mathrm{CT})_{15}$ and $(\mathrm{GT})_{15}$ oligonucleotides. Labelling was performed with terminal transferase (Promega), under the conditions suggested by the manufacturer. Hybridisation was performed at $48^{\circ} \mathrm{C}$ in standard hybridisation solution $(6 \times$ SSC, $0.5 \%$ SDS, $5 \times$ Denhardt's) for at least 16 hours. Membranes were then washed twice for $5 \mathrm{~min}$ in $2 \times \mathrm{SSC} / 0.1 \%$ SDS at $25^{\circ} \mathrm{C}$ and once for $15 \mathrm{~min}$ in $1 \times \mathrm{SSC} / 0.1 \%$ SDS at $37^{\circ} \mathrm{C}$ and subsequently exposed with film. Positive colonies underwent a secondary screening and plasmid DNA was then purified by the alkaline lysis method [62] and electrophoresed. Clones of convenient size inserts (i.e., 500$1000 \mathrm{bp}$ ) were sequenced (Thermo Sequenase core Sequencing kit, Amersham). Sequencing reactions were analysed in an automatic sequenator and the microsatellite repeat motif was determined.
Construction of microsatellite-enriched genomic libraries

Genomic DNA was extracted as above. Enriched libraries were prepared according to [63]. Seven libraries were constructed using different oligonucleotide probes $\left[(\mathrm{GA})_{15}\right.$, $(\mathrm{CA})_{15^{\prime}}(\mathrm{GT})_{15^{\prime}}(\mathrm{CT})_{15^{\prime}}(\mathrm{AT})_{15^{\prime}}(\mathrm{GC})_{15}$ and $\left.(\mathrm{GAC})_{10}\right]$. Two rounds of enrichment were performed for each library. Enriched products were cloned either in plasmid vector pBlueskript SKII digested with EcoRI, (without removal of the amplification linkers), or into the BamHI site of the pUC18 vector (Ready-To-Go ${ }^{\mathrm{TM}}$ pUC18/BamHI, Amersham), (after linker removal). Insert size of recombinant clones was estimated on agarose gels and selected clones were sequenced as above. Selection was done either at random, or after Southern transfer and hybridization with $(\mathrm{GT})_{15}$ and $(\mathrm{CT})_{15}$ radiolabelled probes.

\section{In situ hybridization procedures}

Squash preparations of salivary gland chromosomes were made from 10-12 day-old third instar larvae and 1-2 day old pupae, as previously described [64]. Microsatellite containing clones were labelled with digoxigenated dUTP (Dig-11dUTP) using the random priming method and in situ hybridized to polytene chromosomes according to [64]. Hybridization temperature was $55-62^{\circ} \mathrm{C}$ (Table 1 ). Signals were detected with specific antibodies (ROCHE 
Table 5: Microsatellite loci obtained through cross-species amplification

\begin{tabular}{|c|c|c|}
\hline Locus & B. oleae motif & Motif of other Tephritidae \\
\hline Boms3a & $(\mathrm{GT})_{14}$ & $\begin{array}{l}\text { Bt: }(\mathrm{AT}) \mathrm{G}_{2}(\mathrm{AT})_{3} \mathrm{AC}(\mathrm{AT}) \mathrm{A}_{2}(\mathrm{AT})(\mathbf{G T})_{2}(\mathrm{AT}) /(\mathrm{TG})_{2}(\mathrm{TA})_{2}(\mathrm{TG})_{8} \\
\text { Bco: (TG) })_{2} \mathrm{TA}(\mathrm{GT}) \mathrm{N}_{7}(\mathrm{TG})_{2}(\mathrm{TA}) /(\mathrm{TG})(\mathrm{GA})(\mathrm{TG})_{2}(\mathrm{TA})_{2}(\mathrm{TG})(\mathrm{TA})_{3}\left(\mathrm{TA}_{3}\right)_{2}(\mathrm{TG})_{3} \mathrm{C}(\mathbf{G T})_{3} \\
\text { Bcu: (TA })_{3} \mathrm{~A}(\mathrm{TA}) \mathrm{CA}_{2}(\mathbf{G T})_{4} \\
\left.\text { Bd: (TA })_{2} \mathrm{TG}(\mathrm{TA}) \mathrm{CA}(\mathrm{TA})_{3} \mathrm{~A}_{2} \text { (TG) }\right)_{5} \mathrm{CA}(\mathrm{TG})(\mathrm{TC})_{2}(\mathrm{TA})_{2}(\mathrm{TG})_{7} \\
\text { Cf:(TG) }{ }_{4} \mathrm{~T}_{2}(\mathrm{TG})_{8}\end{array}$ \\
\hline Boms3b & $\begin{array}{l}(\mathrm{CAA})_{3} \mathrm{CAG}(\mathrm{CAA})_{3} / \\
(\mathrm{CAA})_{2} \mathrm{CAG}(\mathrm{CAA})\end{array}$ & $\begin{array}{l}\text { Bco: }(\text { CAA })_{2} \mathrm{AAA}(\mathrm{CAA}) /(\mathrm{CAA})_{3} \\
\text { Bd: (CAA) }{ }_{2} \mathrm{AA}(\mathrm{CAA}) /(\mathrm{CAA})_{5} \\
\text { Bt: (CAA })_{2} \mathrm{~A}(\mathrm{CAA}) /(\mathrm{CAA})_{3} \\
\text { Cc: } /(\text { CAA })_{3}(\text { CAA })_{2} \\
\text { Rc: } \mathrm{A}_{4} \mathrm{CA}_{2} \mathrm{CGATACA}_{5} \mathrm{~N}_{9} A_{5} /(\mathrm{CAA}) \mathrm{G}(\mathrm{CAA})_{2}(\mathrm{CAG})\end{array}$ \\
\hline Boms 10 & $(\mathrm{CA})_{10} \mathrm{GA}(\mathrm{CA})_{2}$ & $\begin{array}{l}\text { Cc: } \\
C f:(C A) G A C(C A)_{4} \\
\text { Rc: - }\end{array}$ \\
\hline Boms II & $(\mathrm{CA})_{7} \mathrm{CG}(\mathrm{CA})_{3}$ & $\begin{array}{l}\text { Bco: - } \\
R c:-\end{array}$ \\
\hline Boms / 4 & $(\mathrm{AT})_{2} \mathrm{GT}(\mathrm{AT})_{\mathrm{I}}$ & $\begin{array}{l}\text { Bco:(TA })_{2} \mathrm{G}(\mathrm{TA}) \mathrm{CA}(\mathrm{TA})_{3} \mathrm{~A}_{2} \\
\text { Af: } \mathrm{G}_{6} \mathrm{~N}_{7}(\mathrm{GT})_{3}\end{array}$ \\
\hline Boms 16 & $(C A)_{10}$ & $\begin{array}{l}\text { Bco: } T_{5} \mathrm{ATCA}{ }_{4} / A_{5} \mathrm{TCA}_{2} \mathrm{~A}_{2} \\
\text { Bd: (CA)TG }(\mathbf{C A})_{4} \\
\text { Bt: (CA)TA(CA }{ }_{4} \mathrm{CG}(\mathbf{C A})\end{array}$ \\
\hline Boms2I & $(\mathrm{GT}) \mathrm{GG}(\mathrm{GT}){ }_{13} \mathrm{AT}(\mathrm{GT})$ & $\begin{array}{l}\text { Bco: }(\mathrm{GA})_{3}(\mathbf{G T})_{6} \\
\text { Bcu: }(\mathrm{AT})_{3}(\mathbf{G T})(\mathrm{AT})(\mathbf{G T})_{7} \\
\text { Bt: }(\mathrm{GA})_{3}(\mathbf{G T})_{3} \mathrm{AT}(\mathbf{G T})_{5} \mathrm{AT}(\mathbf{G T})\end{array}$ \\
\hline Boms60 & $\begin{array}{c}\mathrm{CACA}_{2}\left(\mathrm{CA}_{3}\right)_{2} \\
\mathrm{~A}_{6} \mathrm{CA}_{3} \mathrm{GCA}_{6} \mathrm{TA}_{5} \mathrm{CA}_{4} \mathrm{~N}_{26} \mathrm{~A}_{2} \mathrm{GA}_{9} \mathrm{CGA}_{4}\end{array}$ & 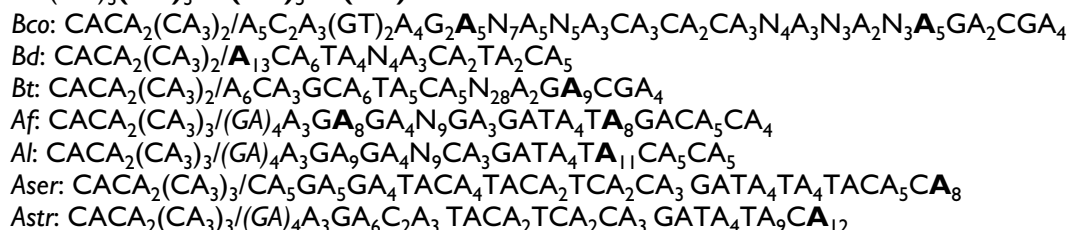 \\
\hline Boms64a & $\mathrm{CAGA}(\mathrm{CA})_{2} \mathrm{C}(\mathrm{CA})_{4} \mathrm{~N}_{12}(\mathrm{CA})_{4} \mathrm{C}(\mathrm{CA})_{2}$ & $B t:(\mathbf{C A})_{2} \mathrm{~A}(\mathbf{C A})_{2} \mathrm{C}(\mathrm{CA}) \mathrm{T}_{2}(\mathbf{C A})_{2}$ \\
\hline
\end{tabular}

In bold: cases of preservation of the expected motif

$\mathrm{N}$ : non-motif bases

Bco: B. correcta; Bcu: B. cucurbitae; Bd: B. dorsalis; Bt: B. tryoni; Cc: C. capitata; Cf: C. fasciventris; Af: A. fraterculus; Al: A. ludens; Aser: A. serpentina; Astr: A. striata; Rc: R. cerasi

Diagnostics, Mannheim, Germany). Five or more chromosomal preparations were hybridized with each probe and at least ten well-spread polytene nuclei per preparation were examined to identify the hybridization signals.

\section{Genotyping}

PCR amplification was performed in a $10 \mu \mathrm{l}$ volume that contained $\sim 10 \mathrm{ng}$ of DNA, $1.6 \mathrm{mM} \mathrm{MgCl}_{2}, 1 \times$ reaction buffer [Promega: 10 mM Tris-HCl (pH 9.0), $50 \mathrm{mM} \mathrm{KCl,}$ $0.1 \%$ Triton X-100], 0.2 U Taq polymerase (Promega), 0.2 $\mathrm{mM}$ of each dNTP, $3 \mathrm{pmol}$ of each primer. PCR products were subsequently separated in $1.5 \%$ agarose gels. For genotyping, PCRs were performed as above with the only difference that one fifth of one of the primers of each pair was end-labeled with $\left[\gamma^{32} \mathrm{P}\right]$-ATP, using T4 polynucleotide kinase (MBI, Fermentas) [65]. Amplification was performed on a PTC-100 thermocycler (MJ Research Inc) for 30 cycles of $1 \mathrm{~min}$ at $95^{\circ} \mathrm{C}, 1 \mathrm{~min}$ at $50^{\circ} \mathrm{C}$ and $1 \mathrm{~min}$ at $72^{\circ} \mathrm{C}$. PCR products were electrophoresed on $5 \%$ denaturing polyacrylamide gels and visualized by autoradiography.

\section{Data analysis}

Genetic variability was measured as the mean number of alleles per locus, effective number of alleles and observed and expected heterozygosity. Conformation to HWE was tested at a significance level of $5 \%$, according to $\mathrm{G}^{2}$ criterion. All computations were performed with POPGENE version 1.31 software [66].

\section{Sequencing of cross-species amplification products}

PCR products were electrophoresed, isolated from gel with the 'PCR Clean up and Gel extraction' kit (Nucleospin) and subsequently ligated to the PCR2.1-TOPO vector with the TOPO TA cloning kit (Invitrogen). Recombinant vectors were used to transform $E$. coli competent cells of the XL-1 strain. Plasmid DNA was extracted with the alkaline lysis method, as above and sequence analysis was performed by Macrogen Inc (Korea).

\section{Authors' contributions}

AAA isolated the microsatellite markers, performed most of the analysis described in the manuscript and drafted 
the largest part of the manuscript. EES participated in the isolation of the microsatellite markers and developed the C. capitata markers. ED carried out the in situ hybridisations and helped to draft the manuscript. EGK participated in the cross-species analysis. PMT analysed the in situ hybridisation results and helped to draft the manuscript. AZ participated in the design of the study, hosted most of the research performed in her laboratory and helped to draft the manuscript. KDM participated in its design and coordination and helped to draft the manuscript. All authors read and approved the final manuscript.

\section{Acknowledgements}

This research was supported by a grant of the Hellenic General Secretariat of Research and Technology ( $99 \mathrm{E} \Delta 529)$. AAA and EES were supported by a Fellowship from the National Fellowship Foundation (Greece). We would like to thank Dr Alan Robinson for providing C. fasciventris, A. ludens, B. dorsalis, B. correcta, B. cucurbitae samples, Dr M. Frommer for B. tryoni and the Campaña Nacional Contra Moscas de la Fruta, Tapachula, Chiapas, Mexico, for providing A. oblique, A. serpentine, A. striata and A. fraterculus.

\section{References}

I. Fletcher BS: Life history strategies of tephritid fruit flies. In Fruit flies, their biology, natural enemies and control Volume 3B. Edited by: Robinson AS, Hooper G. Amsterdam: Elsevier Science Publishers; 1989:195-208.

2. White IM, Elson-Harris MM: Fruit Flies of Economic Significance: Their Identification and Bionomics CAB International \& ACIAR, Wallingford; 1994.

3. Smith JJ, Bush GL: Phylogeny of the genus Rhagoletis (diptera tephritidae) inferred from DNA sequences of mitochondrial cytochrome oxidase II. Molecular Phylogenetics and Evolution I997, 7(I):33-43.

4. Drew RAl: The tropical fruit flies (Diptera: Tephritidae: Dacinae) of the Australasian and Oceanian regions. Memoirs Queensland Museum; 1989:26.

5. Drew RAI, Hancock DL: Phylogeny of the tribe Dacini (Dacinae) based on morphological, distributional, and biological data. In Fruit Flies (Tephritidae): Phylogeny and Evolution of Behavior Edited by: Aluja M, Norrbom AL. Boca Raton, FL: CRC Press; 2000:491-504

6. Mazomenos BE: Dacus oleae. In World crop pests Volume 3B. Edited by: Robinson AS, Hooper G. Elsevier Science Publishers B.V., Amsterdam; 1989:169-177.

7. Montiel-Bueno A, Jones O: Alternative methods for controlling the olive fly, Bactrocera oleae, involving semio-chemicals. IOBC Wprs Bull 2002, 25: I-II.

8. Aketarawong N, Bonizzoni M, Thanaphum S, Gomulski LM, Gasperi G, Malacrida AR, Gugliemino CR: Inferences on the population structure and colonization process of the invasive oriental fruit fly, Bactrocera dorsalis (Hendel). Molecular Ecology 2007 I 6(I 7):3522-3532.

9. Baliraine FN, Bonizzoni M, Guglielmino CR, Osir EO, Lux SA, Mulaa FJ, Gomulski LM, Zheng L, Quilici S, Gasperi G, Malacrida AR: Population genetics of the potentially invasive African fruit fly species, Ceratitis rosa and Ceratitis fasciventris (Diptera: Tephritidae). Molecular Ecology 2004, I3(3):683-695.

10. Duyck P, David P, Junod G, Brunel C, Dupont R, Quilici S: Importance of competition mechanisms in successive invasions by polyphagous tephritids in La Réunion. Ecology 2006, 87(7): 1770-1780.

II. Malacrida AR, Gomulski LM, Bonizzoni M, Bertin S, Gasperi G, Guglielmino CR: Globalization and fruitfly invasion and expansion: The medfly paradigm. Genetica 2007, I 3 I (I): I-9.

12. Thomas DB: Hot peppers as a host for the Mexican fruit fly Anastrepha ludens (Diptera: Tephritidae). Florida Entomologist 2004, 87(4):603-608.
13. Andrewartha HG, Birch LC: Some recent contributions to the study of the distribution and abundance of insects. Annu Rev Entomol 1960, 5:219-242.

14. Whitten MJ: Automated sexing of pupae and its usefulness in control by sterile insects. J Econ Entomol 1969, 62:272-273.

15. Robinson AS: Genetic sexing strains in Medfly, Ceratitis capitata, Sterile Insect Technique Programmes. Genetica 2002, II6:5-13.

16. Economopoulos AP, Avtzis N, Zervas G, Tsitsipis J, Haniotakis G, Tsiropoulos G, Manoukas A: Experiments on control of olive fly, Dacus oleae (Gmelin), by combined effect of insecticides and releases of gamma-ray sterilized insects. Journal of Applied Entomology 1977, 83:20I-2I5.

17. Economopoulos AP, Zervas GA: Sterile insect technique and radiation in insect control. IAEA-SM-255/39 1982:357-368.

18. Zouros E, Loukas M: Biochemical and colonization genetics of Dacus oleae (Gmelin). In Fruit flies, their biology, natural enemies and control Volume 3B. Edited by: Robinson AS, Hooper G. Amsterdam: Elsevier Science Publishers; 1989:75-87.

19. Augustinos AA, Mamuris Z, Stratikopoulos E, D'Amelio S, Zacharopoulou A, Mathiopoulos KD: Microsatellite analysis of olive fly populations in the mediterranean indicates a westward expansion of the species. Genetica 2005, I 25(2-3):23I-24I.

20. Nardi F, Carapelli A, Dallai R, Roderick GK, Frati F: Population structure and colonization history of the olive fly, Bactrocera oleae (Diptera, Tephritidae). Molecular Ecology 2005 I 4(9):2729-2738

21. Mavragani-Tsipidou P: Genetic and cytogenetic analysis of the olive fruit fly Bactrocera oleae (Diptera: Tephritidae). Genetica 2002, II 6 (I):45-57.

22. Lagos D, Koukidou M, Savakis C, Komitopoulou K: The transformer gene in Bactrocera oleae: The genetic switch that determines its sex fate. Insect Molecular Biology 2007 , 16(2):221-230.

23. Lagos D, Ruiz MF, Sainchez L, Komitopoulou K: Isolation and characterization of the Bactrocera oleae genes orthologous to the sex determining Sex-lethal and doublesex genes of Drosophila melanogaster. Gene 2005, 348(I-2 SUPPL.): I I I-I I I.

24. Koukidou M, Klinakis A, Reboulakis C, Zagoraiou L, Tavernarakis N, Livadaras I, Economopoulos A, Savakis C: Germ line transformation of the olive fly Bactrocera oleae using a versatile transgenesis marker. Insect Molecular Biology 2006, I 5(I):95- 103.

25. Bruford MW, Wayne RK: Microsatellites and their application to population genetic studies. Current Opinion in Genetics and Development 1993, 3(6):939-943.

26. Schlötterer C, Pemberton J: The use of microsatellites for genetic analysis of natural populations. EXS 1994, 69:203-2।4.

27. Tautz D, Schlötterer C: Simple sequences. Curr Opin Genet Dev 1994, 4:832-837.

28. Bonizzoni M, Malacrida AR, Guglielmino CR, Gomulski LM, Gasperi $\mathrm{G}$, Zheng L: Microsatellite polymorphism in the mediterranean fruit fly, Ceratitis capitata. Insect Molecular Biology 2000, 9(3):25I-26I.

29. Bonizzoni M, Zheng L, Guglielmino CR, Haymer DS, Gasperi G, Gomulski LM, Malacrida AR: Microsatellite analysis of medfly bioinfestations in California. Molecular Ecology 200I, I0(10):25I5-2524.

30. Bonizzoni M, Guglielmino CR, Smallridge CJ, Gomulski M, Malacrida $A R$, Gasperi G: On the origins of medfly invasion and expansion in Australia. Molecular Ecology 2004, I 3(I 2):3845-3855.

31. Gasperi G, Bonizzoni M, Gomulski LM, Murelli V, Torti C, Malacrida AR, Guglielmino CR: Genetic differentiation, gene flow and the origin of infestations of the medfly, Ceratitis capitata. Genetica 2002, I | 6: 125-135.

32. Stratikopoulos EE, Augustinos AA, Petalas YG, Vrahatis MN, Mintzas A, Mathiopoulos KD, Zacharopoulou A: An integrated genetic and cytogenetic map for the Mediterranean fruit fly, Ceratitis capitata, based on microsatellite and morphological markers. Genetica 2008, 133:147-157.

33. Song SD, Drew RAI, Hughes JM: Multiple paternity in a natural population of a wild tobacco fly, Bactrocera cacuminata (Diptera: Tephritidae), assessed by microsatellite DNA markers. Molecular Ecology 2007, I6(I I):2353-236I.

34. Bonizzoni M, Katsoyannos BI, Marguerie R, Guglielmino CR, Gasperi G, Malacrida A, Chapman T: Microsatellite analysis reveals 
remating by wild Mediterranean fruit fly females, Ceratitis capitata. Molecular Ecology 2002, I I (10):1915-192I.

35. Kraaijeveld K, Katsoyannos BI, Stavrinides M, Kouloussis NA, Chapman T: Remating in wild females of the Mediterranean fruit fly, Ceratitis capitata. Animal Behaviour 2005, 69(4):77/-776.

36. Augustinos AA, Stratikopoulos EE, Zacharopoulou A, Mathiopoulos KD: Polymorphic microsatellite markers in the olive fly, Bactrocera oleae. Molecular Ecology Notes 2002, 2(3):278-280.

37. Bachtrog D, Weiss S, Zangerl B, Brem G, Schlötterer C: Distribution of dinucleotide microsatellites in the Drosophila melanogaster genome. Mol Biol Evol 1999, 16(5):602-610.

38. Katti MV, Ranjekar PK, Gupta VS: Differential distribution of simple sequence repeats in eukaryotic genome sequences. Mol Biol Evol 200I, 18(7): II6I-II67.

39. Schug MD, Wetterstrand KA, Gaudette MS, Lim RH, Hutter CM, Aquadro CF: The distribution and frequency of microsatellite loci in Drosophila melanogaster. Molecular Ecology 1998, 7:57-70.

40. Hutter CM, Schug MD, Aquadro CF: Microsatellite variation in Drosophila melanogaster and Drosophila simulans: $A$ reciprocal test of the ascertainment bias hypothesis. Mol Biol Evol 1998, I 5(12):1620-1636.

41. Zheng L, Benedict MQ, Cornel AJ, Collins FH, Kafatos FC: An integrated genetic map of the African human malaria vector mosquito, Anopheles gambiae. Genetics 1996, 143:94I-952.

42. Estoup A, Solignac M, Harry M, Cornuet J: Characterization of $(\mathrm{GT})(\mathrm{n})$ and $(\mathrm{CT})(\mathrm{n})$ microsatellites in two insect species: Apis mellifera and Bombus terrestris. Nucleic Acids Research 1993, 2 I(6): |427-|43|.

43. Kinnear MW, Bariana HS, Sved JA, Frommer M: Polymorphic microsatellite markers for population analysis of a tephritid pest species, Bactrocera tryoni. Molecular Ecology 1998, 7(II): 1489-1495.

44. Reddy KD, Abraham EG, Nagaraju J: Microsatellites in the silkworm, Bombyx mori: Abundance, polymorphism, and strain characterization. Genome 1999, 42(6): 1057-1065.

45. Noor MAF, Schug MD, Aquadro CF: Microsatellite variation in populations of Drosophila pseudoobscura and Drosophila persimilis. Genetical Research 2000, 75(I):25-35.

46. Harr B, Schlötterer C: Patterns of microsatellite variability in the Drosophila melanogaster complex. Genetica 2004, I20(I3):7I-77

47. Rubinsztein DC, Amos W, Leggo J, Goodburn S, Jain S, Li S, Margolis RL, Ross CA, Ferguson-Smith MA: Microsatellite evolution - Evidence for directionality and variation in rate between species. Nature Genetics 1995, 10(3):337-343.

48. Segura MD, Callejas C, Fernaìndez MP, Ochando MD: New contributions towards the understanding of the phylogenetic relationships among economically important fruit flies (Diptera: Tephritidae). Bulletin of Entomological Research 2006, 96(3):279-288.

49. Han HY: Molecular phylogenetic study of the tribe Trypetini (Diptera: Tephritidae), using mitochondrial I6S ribosomal DNA sequences. Biochemical systematics and Ecology 2000, 120:50|-513.

50. Han HY, McPheron BA: Molecular phylogenetic study of tephritidae (insecta: diptera) using partial sequences of the mitochondrial I6S ribosomal DNA. Molecular phylogenetics and Evolution 1997, 7:17-32.

5I. Han HY, McPheron BA: Phylogenetic study of selected Tephritid flies (Insecta: Diptera: Tephritidae) using partial sequences of the nuclear $18 \mathrm{~s}$ ribosomal DNA. Biochemical systematics and Ecology 1994, 22:444-457.

52. Chirhart SE, Honeycutt RL, Greenbaum IF: Microsatellite variation and evolution in the Peromyscus maniculatus species group. Molecular Phylogenetics and Evolution 2005, 34(2):408-4I5.

53. Goldstein DB, Pollock DD: Launching microsatellites: $\mathbf{A}$ review of mutation processes and methods of phylogenetic inference. Journal of Heredity 1997, 88(5):335-342.

54. Schlötterer C: Genealogical inference of closely related species based on microsatellites. Genetical Research 2001, 78:209-2/2.

55. Kounatidis I, Papadopoulos N, Bourtzis K, Mavragani-Tsipidou P. Genetic and cytogenetic analysis of the fruit fly Rhagoletis cerasi (Diptera: Tephritidae). Genome 2008, 5 I (7):479-49।

56. Zacharopoulou A: Polytene chromosome maps in the Medfly Ceratitis capitata. Genome 1990, 33:184-197.
57. Zacharopoulou A, Frisardi M, Savakis C, Robinson AS, Tolias P, Konsolaki M, Komitopoulou K, Kafatos FC: The genome of the Mediterranean fruit fly $C$. capitat a: Localization of molecular markers by in situ hybridization to salivary gland polytene chromosomes. Chromosoma 1992, 101:448-455.

58. Tsitsipis JA: An improved method for the mass rearing of the olive fruit fly, Dacus oleae (Gmel.) (Diptera, Tephritidae). Z Angrew Entomol 1977, 83:419-426.

59. Tsitsipis JA: Development of a caging and egging system for mass rearing the olive fruit fly, Dacus oleae (Gmel.) (Diptera, Tephritidae). Ann Zool Ecol Anim 1977, 9:133-139.

60. Tzanakakis ME, Economopoulos AP, Tsitsipis JA: The importance of conditions during the adult stage in evaluating an artificial food for larvae of Dacus oleae (Gmel.) (Diptera, Tephritidae). Z Angew Entomol 1967, 59:127-130.

61. Ashburner M: Drosophila: A Laboratory Manual New York: Cold Spring Harbour Laboratory Press; 1989.

62. Sambrook J, Fritch EF, Maniatis T: Molecular Cloning: A Laboratory Manual Cold Spring Harbor, NY. 21: Cold Spring Harbor Laboratory press; 1989.

63. Schlötterer C: Microsatellites. In Molecular Genetic Analysis of Populations: a practical approach Edited by: Hoelzel AR. Oxford University Press; 1998:238-245.

64. Zambetaki A, Zacharopoulou A, Scouras ZG, Mavragani-Tsipidou P: The genome of the olive fruit fly Bactrocera oleae: Localization of molecular markers by in situ hybridization to the salivary gland polytene chromosomes. Genome 1999, 42(4):744-75I.

65. Zheng L: Microsatellite mapping of insect genomes. In Molecular Biology of Insect Disease Vectors: A methods manual Edited by: Crampton JM, Beard CB, Louis C. Chapman \& Hall; 1997:32I-329.

66. Yeh FC, Yang RC, Boyle TBJ, Ye ZH, Mao JX: POPGENE, the userfriendly shareware for population genetic analysis. Molecular Biology and Biotechnology Centre, University of Alberta, Canada; 1997.

Publish with Biomed Central and every scientist can read your work free of charge

"BioMed Central will be the most significant development for disseminating the results of biomedical research in our lifetime. "

Sir Paul Nurse, Cancer Research UK

Your research papers will be:

- available free of charge to the entire biomedical community

- peer reviewed and published immediately upon acceptance

- cited in PubMed and archived on PubMed Central

- yours - you keep the copyright
BioMedcentral 